\title{
BIM (Building Information Modeling) Education Program in KSA: A Case Study of BIM program at Prince Sultan University
}

\author{
TaeYeua $\mathrm{Yi}^{1 *}$ and SukHee Yun ${ }^{2}$ \\ ${ }^{1}$ Faculty of Engineering Management Department, College of Engineering, Prince Sultan University, \\ Rafha Street, Riyadh 11586, Kingdom of Saudi Arabia \\ ${ }^{2}$ Faculty of Architectural Engineering Department, College of Engineering, Prince Sultan University, \\ Rafha Street, Riyadh 11586, Kingdom of Saudi Arabia
}

\begin{abstract}
A variety of BIM education programs have been developed and strengthened for future architects and engineers around the world. BIM education curricula as architecture and civil engineering education programs have held an important position in the education institutes. The purpose of the study is to provide future architects and civil engineers with solid hand-on knowledge about BIM through the understanding of its theoretical and historical backgrounds as well as the practical exercise examples of the related various BIM methods, which also shows the benefits of various BIM processes and methods as used by all relevant stakeholders in the AEC industry, such as clients, design teams, construction manager, contractors and maintenance operators etc. Additionally, the paper introduces other related topics as follows through the case studies at PSU for BIM education program, 1) Create 3D BIM models that extract quantities for estimation purposes on the basis of input resources. 2) Operate construction schedule (4D simulation) for project planning. 3) Explore a virtual construction management process that integrated 3D BIM model with scheduling and costing, what is called, 5D simulation. Through the case study, the paper proposes a BIM education guideline appropriate for KSA.
\end{abstract}

\section{Introduction}

\subsection{Research background}

As a new technology in the AEC industry today, the advent of BIM reflects the increasingly digital, multi-disciplinary, collaboration and integrated nature of architecture and construction project delivery, first of all, influenced by the strong demand from clients and governments. It is quite important for universities to teach new technologies in architecture and construction education curriculum (Ali Abbas et al., 2016). To satisfy the industry

\footnotetext{
*Corresponding author: tyyi@psu.edu.sa
} 
demand for engineers and architects with BIM skills, many universities around the world have started to integrate BIM into their academic programs of architecture, engineering, and construction (Pikas and Hazzan, 2013).

In this respect, the implementation of BIM education in KSA is still in the initial stages. In facts, there are few universities and education institutes to teach BIM on their regular courses for the future architects, civil engineers and construction managers in KSA.

\subsection{Research objective}

The paper explores the meaning of BIM as a new paradigm shift of AEC industry and first of all, the reason why many governments around the world have mandated or are planning to mandate BIM in their AEC industry. Secondly, the study considers BIM as a core education program for future Saudi architects and civil engineers and provides future Saudi architects and civil engineers with solid hand-on knowledge about BIM through the understanding of its theoretical and historical backgrounds as well as the practical exercise examples of the related various BIM methods.

Lastly, the paper introduces PSU BIM education program as a case study to future Saudi architects and civil engineers, the main contents of which are to create the 3D BIM construction model that extract material quantities for cost management and to operate the virtual 4D simulation for the schedule management and to explore the virtual construction management process that integrated 3D BIM model with scheduling and costing, what is called, 5D simulation.

On accordance with the above outcomes, the study proposes a BIM education guileline adequate for KSA's AEC industry.

\section{$2 \mathrm{BIM}$ as a new paradigm shift in AEC industry}

\subsection{Value of BIM in AEC industry}

According to the SmartMarket Report by McGraw-Hill Construction (2012), The adoption of BIM in North American construction industry including other developed countries had rapidly increased from $28 \%$ in 2007 to $71 \%$ in 2012 (Figure 1).

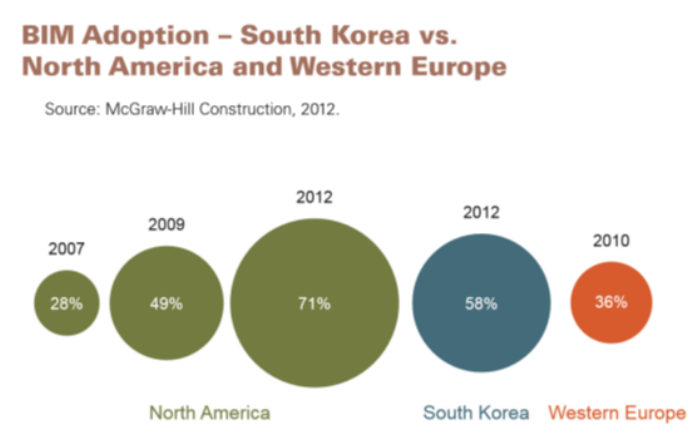

Fig. 1. Increase in BIM adoption 2007-2012

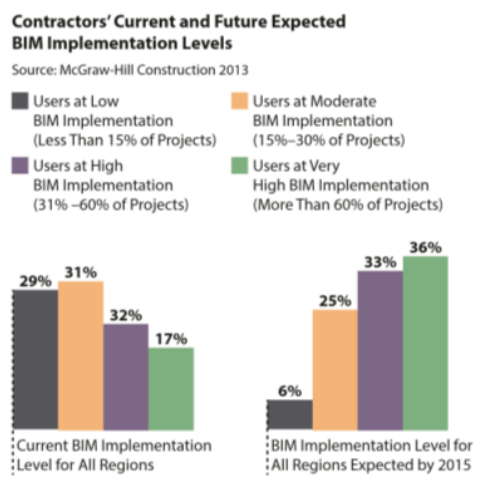

Fig. 2. Expected growth trends of BIM

Many firms and vendors in AEC industry around the world are willing to invest to drive efficiencies, as is evident in the rise of contractors adopting BIM technologies (Figure 2). 
The core value of BIM that the construction industry should be aware of is the ability to take model information and extend its use by giving it meaning for other related workflows and processes. These workflows include impacts to basic functionality such as estimating, scheduling, logistics, and safety. These new capabilities have opened doors for faster population of data into these systems to deliver work earlier, safer, and better quality (Brad and Dave, 2015).

\subsection{BIM as a national guideline for AEC industry}

A number of national governments have mandated and are planning to mandate BIM in their AEC industry.

The following Table 1, BIM National Guidelines show the current situation of each country's efforts and policy to adopt BIM in the AEC industry. Unfortunately, Kingdom of Saudi Arabia doesn't have any specific guidelines yet to take advantage of using BIM in its AEC industry. However, KSA is also expected to adopt BIM in the near future as a national guideline in order to strengthen the competitiveness of its AEC industry.

Table 1. BIM National Guidelines

\begin{tabular}{|c|c|c|c|}
\hline Nation & Government Guidelines & BIM Tools & Remarks \\
\hline US & $\begin{array}{l}\text {-2005, charted BIM National Standard, } \\
\text { "NBIMS(National BIM Standard)" } \\
\text {-2007, mandated the use of BIM format } \\
\text { to be submitted on all federal } \\
\text { facilities(buildings) in US(GSA) }\end{array}$ & $\begin{array}{l}\text { - Revit } \\
\text { - Tekla Structure } \\
\text { - Bentley } \\
\text { - Digital Project } \\
\text { - etc. }\end{array}$ & $\begin{array}{l}\text { Not allowed 2D based- } \\
\text { CAD tools, AutoCAD } \\
\text { 3D, 3DMax, FormZ, } \\
\text { and even SketchUp), } \\
\text { which are only } \\
\text { supplementary tools. }\end{array}$ \\
\hline UK & $\begin{array}{l}\text {-2011, mandated the use of BIM by UK } \\
\text { Government (Cabinet Office) } \\
\text {-Supported by an AEC(UK) BIM } \\
\text { Standard Committee } \\
\text {-UK Government requires fully } \\
\text { collaborative 3D BIM in all public area } \\
\text { as a minimum by } 2016\end{array}$ & $\begin{array}{l}\text { - Revit } \\
\text { - ArchiCAD } \\
\text { - Digital Project } \\
\text { - Bentley } \\
\text { - Vecterworks } \\
\text { - etc. }\end{array}$ & $\begin{array}{l}\text {-AEC firms in UK: } \\
\text { Foster and Partner, Zaha } \\
\text { Hadid Architect, BDP } \\
\text { and international } \\
\text { headquarters, HOK, } \\
\text { SOM, Gensler etc. }\end{array}$ \\
\hline $\begin{array}{l}\text { European } \\
\text { Countries }\end{array}$ & $\begin{array}{l}\text {-Nordics: Finland(2002), Norway(2005), } \\
\text { Demark(2007) - All public buildings } \\
\text {-Netherlands (2012) : mandated BIM by } \\
\text { Ministry of Interier "RGD" } \\
\text {-Germany : Publised "User Handbook } \\
\text { Data Exchange BIM/IFC", charted BIM } \\
\text { guidelines by } 2014\end{array}$ & $\begin{array}{l}\text { - ArchiCAD } \\
\text { - Vectorworks } \\
\text { - Allplan } \\
\text { - Digital Project } \\
\text { - etc. }\end{array}$ & $\begin{array}{l}\text {-Jan. 2014, European } \\
\text { Parliamentary voted to } \\
\text { encourage, specify or } \\
\text { mandate the use of BIM } \\
\text { for public construction } \\
\text { and building projects by } \\
2016\end{array}$ \\
\hline $\begin{array}{c}\text { Asian } \\
\text { Countries }\end{array}$ & $\begin{array}{l}\text {-Singapore: mandated BIM by } 2012 \\
\text {-South Korea: } 2012 \text {, mandated BIM in } \\
\text { public projects(over US } \$ 55,000,000) \text {, } \\
\text { all public areas by } 2016 . \\
\text {-Japan : applying BIM by the public } \\
\text { institute, "JACIC(Japan Construction } \\
\text { Information Center) }\end{array}$ & $\begin{array}{l}\text { - Revit } \\
\text { - ArchiCAD } \\
\text { - Digital Project } \\
\text { - Tekla Structure } \\
\text { - Vectorworks } \\
\text { - etc. }\end{array}$ & \\
\hline KSA & $?$ & $?$ & $?$ \\
\hline
\end{tabular}

\section{BIM education program around the world}

According to the report, "Embedding Building Information Modeling (BIM) within the target curriculum" that produced by the BIM Academic Forum UK (BAF), 2013, there are 
60 members from 29 higher Education Institutes across the UK including universities from Republic of Ireland.

The BIM Academic Forum (BAF) is a group of representatives from a large number of UK universities formed to promote the academic aspects of BIM. In particular, BAF is focused on the development of a 'BIM academic framework', the aim of which is to propose a roadmap towards a longer-term vision of embedding BIM learning at the appropriate levels within 'discipline-specific' undergraduate and postgraduate education (BAF, 2013).

In the US, there are several BIM degree programs at various levels to support AEC industry which include Civil Engineering, Architecture, Architectural Engineering, Construction Engineering and Construction Management (Ali and Zia, 2016). The following Table 2 introduces specific BIM courses in some US universities.

Table 2. BIM courses in the US universities

\begin{tabular}{|l|l|l|}
\hline \multicolumn{1}{|c|}{ Course No. } & \multicolumn{1}{c|}{ Course Name } & \multicolumn{1}{c|}{ University } \\
\hline CNMG 2318 & Building Information Modeling & University of Arkansas at Little \\
\hline ARC 1300P & $\begin{array}{l}\text { Building Information Modeling for } \\
\text { Construction Management }\end{array}$ & Georgia Institute of Technology \\
\hline CEE 110/210 & Building Information Modeling & Stanford University \\
\hline CM 1223 & Graphic Communication Skills & John Brown University \\
\hline CM 414 & Virtual Construction & University of Washington \\
\hline CM 470 & BIM and Integrated Practices & University of Southern California \\
\hline AE 597G & $\begin{array}{l}\text { Building Information Modeling } \\
\text { Execution Planning }\end{array}$ & Pennsylvania State University \\
\hline CGT 46000 & BIM for Commercial Construction & Purdue University \\
\hline MCM 602 & Construction Information Modeling & Philadelphia University \\
\hline ECIV 309 & BIM in Construction & Montana State University \\
\hline CM 4 & Construction Graphics & California State University \\
\hline AE 1312 & Introduction to BIM & Milwaukee School of Engineering \\
\hline ENGR 2100 & Intro to Engr/Computer Graphics & Clemson University \\
\hline
\end{tabular}

Almost 30 universities in the US are accredited to provide undergraduate programs in all three of the AEC disciplines and all of which offer some 'BIM courses' as part of the syllabus. For other countries' BIM education, the report, NATSPEC, BIM education global-2017 updated (2017) version needs to be considered as following Table 3. BIM education around the world.

Table 3. BIM education around the world

\begin{tabular}{|c|c|c|}
\hline Nation & Education & Institution \\
\hline Australia & $\begin{array}{l}11 \text { institutions have shown the greatest uptake of } \\
\text { BIM in their undergraduate curricula. Construction } \\
\text { Management programs appear to be showing the } \\
\text { fastest creation/uptake of BIM education courses. } \\
\text { Many technical colleges are providing courses } \\
\text { where BIM is incorporated into the syllabus. }\end{array}$ & $\begin{array}{l}\text { Australian Institute of Architects } \\
\text { Australasian Procurement and } \\
\text { Construction Council } \\
\text { Australian Construction Industry } \\
\text { Forum } \\
\text { Australasian BIM Advisory } \\
\text { Board }\end{array}$ \\
\hline Canada & $\begin{array}{l}\text { buildingSMARTCanada (bSC) and Canada BIM } \\
\text { Council(CanBIM) are jointly moving ahead with } \\
\text { the implementation of the Canadian BIM Education } \\
\text { Strategy. }\end{array}$ & $\begin{array}{l}\text { BuildingSMARTCanada (bSC) } \\
\text { Canada BIM Council (CanBIM) } \\
\text { Institute for BIM in Canada } \\
\text { (IBC) }\end{array}$ \\
\hline Finland & $\begin{array}{l}\text { Universities and polytechnics provide BIM } \\
\text { education. Large companies such as Skanska and }\end{array}$ & $\begin{array}{l}\text { National Common BIM } \\
\text { (COBIM) }\end{array}$ \\
\hline
\end{tabular}




\begin{tabular}{|l|l|l|}
\hline & $\begin{array}{l}\text { Senaatti arrange focused in-house training as } \\
\text { required. The Skanska use BIM for } 100 \% \text { of its } \\
\text { own production. }\end{array}$ & buildingSMARTFinland \\
\hline Singapore & $\begin{array}{l}\text { There are 11 Institutes of Higher Learning (IHLs) } \\
\text { providing a total of 33 full-time programmes and }\end{array}$ & $\begin{array}{l}\text { Nanyang Technological } \\
\text { University }\end{array}$ \\
$\begin{array}{l}\text { Third-party BIM software educational vendors } \\
\text { were also crucial in training, especially for } \\
\text { professionals. }\end{array}$ & $\begin{array}{l}\text { National University of Singapore } \\
\text { Institutes of Higher Learning } \\
\text { (IHLs) } \\
\text { Building and Construction } \\
\text { Authority Academy (BCAA) }\end{array}$ \\
\hline
\end{tabular}

\section{Prince Sultan University BIM Course}

\subsection{Course overview}

The EM 428 Special Topics course, BIM Construction Management has been providing the senior students with a solid hand-on knowledge about BIM through the understanding of its theoretical and historical backgrounds as well as the practical exercises of the related various BIM software tools for the last 5 semesters. The course aims to make students understand the benefits of BIM processes and methods in the AEC industry, especially as the aspects of all relevant stakeholders, such as clients, design teams, construction manager, contractors and maintenance operators etc.

\subsection{Course objectives}

The course is designed to provide senior students of construction management with the meaning of BIM, the BIM process as a new way of thinking throughout the project life cycle viewpoints, hands-on practice with BIM software tools and the collaboration through the team and individual project. By studying this course, the students will be able to (1) Understand a variety of 3D BIM drawings and Modeling, (2) Illustrate how to apply BIM process to construction management areas, (3) Show how to use BIM tools as new technologies in the field of AEC industry, (4) Demonstrate how to do 3D Modeling by applying various BIM tools, (5) Analyze differences between 2D-based conventional process and $3 \mathrm{D}$-based BIM process in the AEC industry.

\subsection{Course learning outcomes}

Upon completion of this course, the students are expected to achieve the following: (1) Develop skills to deliver better value through integrated construction and project delivery, (2) Reproduce 3D Models and their related BIM software, (3) Evaluate team work skill through a group project, (4) Analyze budgeting and quality managing including scheduling on the basis of BIM concept, (5) Recognize modeling works with various software tools, such as Revit, Navisworks, and other related BIM tools, (6) Illustrate 3D(4D,5D) Models in order to describe building projects that cover schedule management and cost management areas.

\subsection{Course structure}


The course basically consists of two learning structures, both theoretical and technical part(Table 4). Especially, the learning of various BIM software tools as the technical part in the course is extremely important for students to understand the meaning of BIM because it is impossible to know BIM perfectly without handling with BIM software tools.

Table 4. BIM Construction Management Course Program

\begin{tabular}{|c|c|c|c|c|}
\hline Step & Theoretical Part & Technical Part & BIM tools & Role \\
\hline 1 & $\begin{array}{l}\text { The meaning of BIM in the AEC } \\
\text { industry } \\
\text { The differences between BIM } \\
\text { model and normal 3D model }\end{array}$ & $\begin{array}{l}\text { 3D Structural \& } \\
\text { Architectural } \\
\text { Modeling for } 5 \text { story- } \\
\text { office building }\end{array}$ & $\begin{array}{l}\text { AutoCAD, } \\
\text { Tekla } \\
\text { Structure \& } \\
\text { Revit }\end{array}$ & $\begin{array}{l}\text { Client, } \\
\text { Architect, } \\
\text { Structure } \\
\text { Engineer }\end{array}$ \\
\hline 2 & $\begin{array}{l}\text { Technology, BIM is so important } \\
\text { to AEC industry } \\
\text { Historical Background of BIM } \\
\text { Open BIM \& Interoperability } \\
\text { 3D Model base Design }\end{array}$ & $\begin{array}{l}\text { Extract 2D drawings } \\
\text { from 3D Model (Plan, } \\
\text { Sections, Elevations } \\
\text { etc.) } \\
\text { Model Import \& } \\
\text { Export by IFC file } \\
\end{array}$ & $\begin{array}{c}\text { Revit \& } \\
\text { ArchiCAD }\end{array}$ & Architect \\
\hline 3 & $\begin{array}{l}\text { The value of BIM in the AEC } \\
\text { industry } \\
\text { Building Life Cycle viewpoint, }\end{array}$ & $\begin{array}{l}\text { Estimate the building } \\
\text { project's Quantity \& } \\
\text { Cost from 3D Model }\end{array}$ & $\begin{array}{l}\text { Revit \& } \\
\text { Excel }\end{array}$ & $\begin{array}{l}\text { Procurement } \\
\text { Manager } \\
\text { Cost Manager }\end{array}$ \\
\hline 4 & $\begin{array}{l}\text { Collaboration } \\
\text { Parametric function } \\
\text { Cost reduction } \\
\text { 3D printing (Contour Crafting) }\end{array}$ & $\begin{array}{l}\text { Clash Detection } \\
\text { Animation \& } \\
\text { Navigation into 3D } \\
\text { Model }\end{array}$ & Navisworks & $\begin{array}{l}\text { Quality } \\
\text { Manager }\end{array}$ \\
\hline 5 & $\begin{array}{l}\text { Schedule Management } \\
\text { Project Delivery Methods: } \\
\text { Integrated Project Delivery (IPD) }\end{array}$ & $\begin{array}{l}\text { Define Activity for 3D } \\
\text { Model, Create WBS } \\
\text { Estimate Activity } \\
\text { Resource, Develop } \\
\text { Schedule }\end{array}$ & $\begin{array}{l}\text { Primavera } \\
\text { P6 \& } \\
\text { Navisworks }\end{array}$ & $\begin{array}{l}\text { Planner \& } \\
\text { Scheduler }\end{array}$ \\
\hline 6 & $\begin{array}{l}\text { Level of Development (LOD) } \\
\text { BOQ Documentation }\end{array}$ & $\begin{array}{l}\text { Estimate BOQ } \\
\text { Determine Budget }\end{array}$ & $\begin{array}{l}\text { Primavera } \\
\text { P6, Excel \& } \\
\text { Navisworks }\end{array}$ & $\begin{array}{c}\text { Scheduler } \\
\text { Cost Manager }\end{array}$ \\
\hline 7 & $\begin{array}{l}\text { 4D: 3D Model + Time } \\
\text { 5D: 4D Model + Cost }\end{array}$ & 4D \& 5D Simulation & Navisworks & $\begin{array}{c}\text { Civil } \\
\text { Engineer } \\
\text { Scheduler }\end{array}$ \\
\hline 8 & $\begin{array}{l}\text { 6D: 5D Model + Energy } \\
\text { The future of BIM }\end{array}$ & $\begin{array}{l}\text { Document sheets, } \\
\text { Image Rendering, } \\
\text { Animation Video }\end{array}$ & $\begin{array}{c}\text { Revit \& } \\
\text { Navisworks }\end{array}$ & $\begin{array}{l}\text { Architect } \\
\text { Construction } \\
\text { Manager }\end{array}$ \\
\hline
\end{tabular}

\subsection{Course assessment}

The students will be learning knowledge and competencies that will be evaluated using different assessment techniques. The following grading percentages will be allocated: Assignments and Individual Project: 10\%, Team Project: 10\%, 2-Mid-Term Exam: 20\% and Final Exam: 30\%. All grading criteria places an emphasis on using BIM software tools and other related software tools, such as Revit, Tekla Structure, Navisworks including Primavera P6 \& AutoCAD. 


\section{Outcomes of BIM construction management course}

\subsection{D modeling by Revit \& Tekla structure}

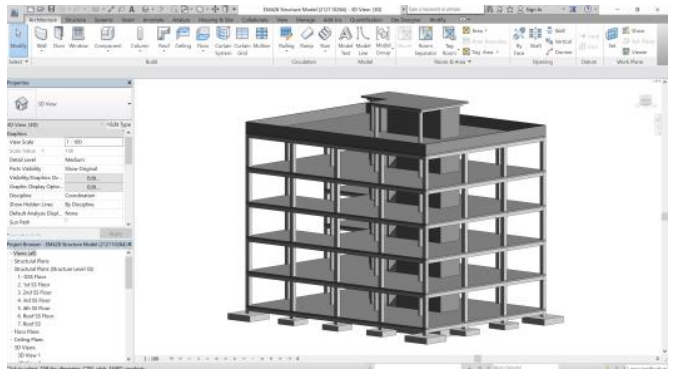

Fig. 4. Structural Modeling by Revit

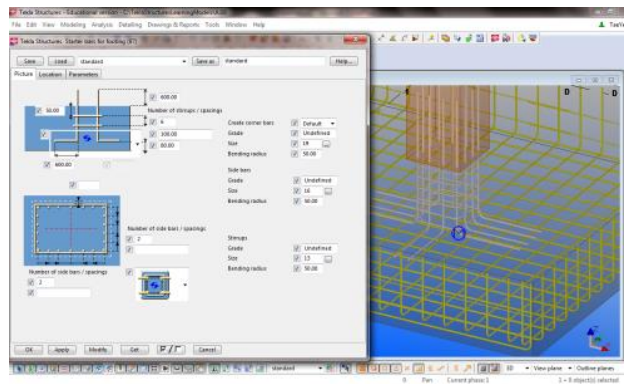

Fig. 5. Isolated Footings by Tekla Structure

The course instructor had provided students with 2D-based AutoCAD drawing-sets that are to regards with the RC (Reinforced Concrete) structure building. The students were required to import all AutoCAD 2D drawings into Revit for the purpose of creating a 3D BIM structural model (Figure 4). In the case of the foundation structure which consists of several type-isolated footings with neck columns, the students were able to do 3D isolated footings' modeling with the re-bars installation by using Tekla Structure (Figure 5).

After the completion of the structural modeling, the students could start architectural modeling on the basis of structure model by using Revit. Basically, the course instructor had shared students with the space program and architectural materials schedule, which contains material types and quantity according to the locations, rooms and floors (Table 5).

Table 5. Space Program and Architecture Materials Schedule

\begin{tabular}{|c|c|c|c|c|c|}
\hline Floors & Spaces & No. & Floor & Ceiling & Door \\
\hline \multirow{4}{*}{$\begin{array}{l}\text { Ground } \\
\text { Floor }\end{array}$} & Office Room & 3 & Tile, Mosaic, Gray/THK.100 & $\begin{array}{c}\text { Acoustic Ceiling Tile } \\
24^{*} 48 / \text { H. } 2,800 / \text { THK. } 50\end{array}$ & Double Door/3EA, Free \\
\hline & Lobby & 1 & Tile, Mosaic, Gray/THK.100 & $\begin{array}{c}\text { Acoustic Ceiling Tile } \\
24^{*} 48 / \text { H.2, } 800 / \text { THK. } 50\end{array}$ & Double Door/1EA, Free \\
\hline & Toilet & 1 & Tile, Porcelain, 4in/THK.100 & Aluminum/H.3,000/ТHK.50 & Single Door/1EA, Free \\
\hline & Computer Room & 1 & Default Mass Floor/THK. 300 & $\begin{array}{c}\text { Acoustic Ceiling Tile } \\
24^{*} 48 / \text { H. } 2,800 / \text { THK. } 50\end{array}$ & Single Door/1EA, Free \\
\hline \multirow{5}{*}{ 1st Floor } & Office Room & 4 & Tile, Mosaic, Gray/THK.100 & $\begin{array}{c}\text { Acoustic Ceiling Tile } \\
24^{*} 48 / \text { H. } 2,800 / \text { THK. } 50\end{array}$ & Double Door/4EA, Free \\
\hline & Elevator Hall & 1 & Tile, Mosaic, Gray/THK.100 & $\begin{array}{c}\text { Acoustic Ceiling Tile } \\
24^{*} 48 / \text { H. } 2,800 / \text { THK. } 50\end{array}$ & Double Door/1EA, Free \\
\hline & Toilet & 1 & Tile, Porcelain, 4in/THK.100 & Aluminum/H.3,000 & Single Door/1EA, Free \\
\hline & Computer Room & 1 & Default Mass Floor/THK.300 & $\begin{array}{c}\text { Acoustic Ceiling Tile } \\
24^{*} 48 / \text { H. } 2,800 / \text { THK. } 50\end{array}$ & Single Door/1EA, Free \\
\hline & Balcony & 1 & Tile, Porcelain, 4 in/THK.100 & N/A & Single Door/1EA, Free \\
\hline
\end{tabular}

Finally, they had finalized a 3D architectural model and were able to extract various drawings such as plans, sections, elevations, perspective $\&$ isometric views, rendering views etc., from the model (Figure.6). 


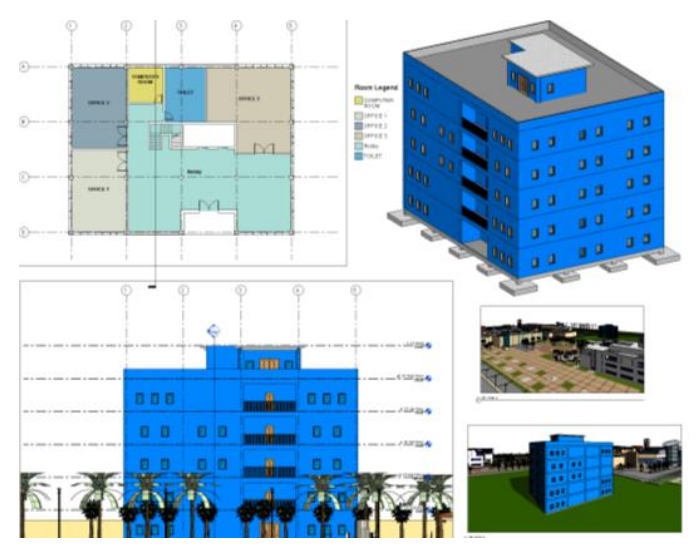

Fig. 6. Various drawings from the architecture BIM model

\subsection{Materials quantity estimating}

The students were required to extract all related materials from their own completed architectural model by using the Schedule/Quantities function of Revit. All extracted materials could be divided into two scopes to quantity take-off, structural scope and architectural scope. The structural scope consists of foundation, framing(beam), slab(floor), wall, and staircase, the material of which mainly used concrete. As the architectural scope, there are door, window, ceiling, architectural wall, floor \& wall finishing, handrails etc. They would be estimated on the basis of their own measurement units, such as volume, area, and count.

\subsection{Cost estimating and BOQ documentation}

On the basis of the estimated materials quantities, the students could perform to do documentation for the BOQ (Bill of Quantity) of their building project. The project BOQ is composed of 3 main categories, material, labor and equipment in accordance with the estimated each material. The course instructor had provide them with all unit's costs against each unit materials quantity. As a result, they could estimate total construction cost for their building project. Finally, the students were able to prepare a Bill of Quantity (BOQ) document in compliance with the cost bills of quantities that is estimated from the Revit model (Table 6). 
Table 6. Bill of Quantity - BIM Project

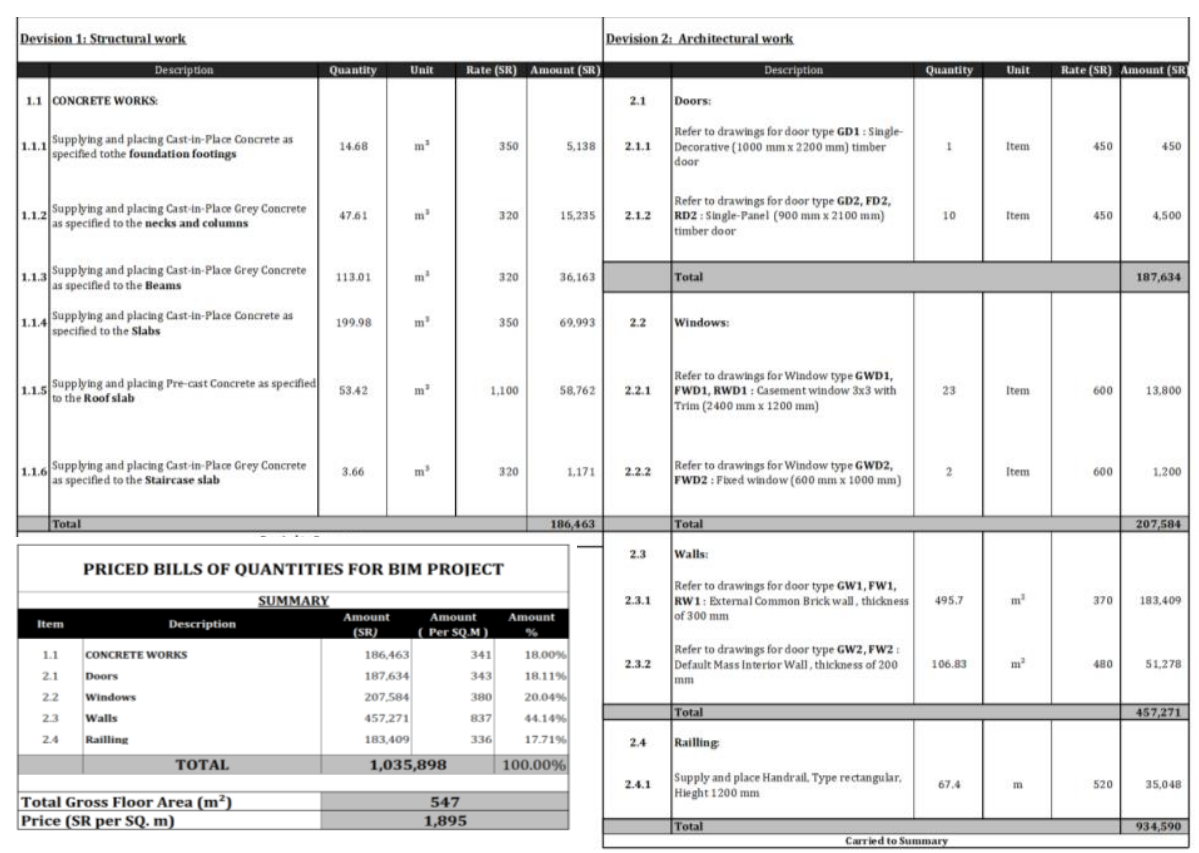

\subsection{D and 5D simulation modeling}

As a schedule and planning software tool, Primavera P6 is used to create work activities in accordance with real construction process with the 3D Revit model and build up its construction schedule with the clear relationship between all activities (Figure 7).
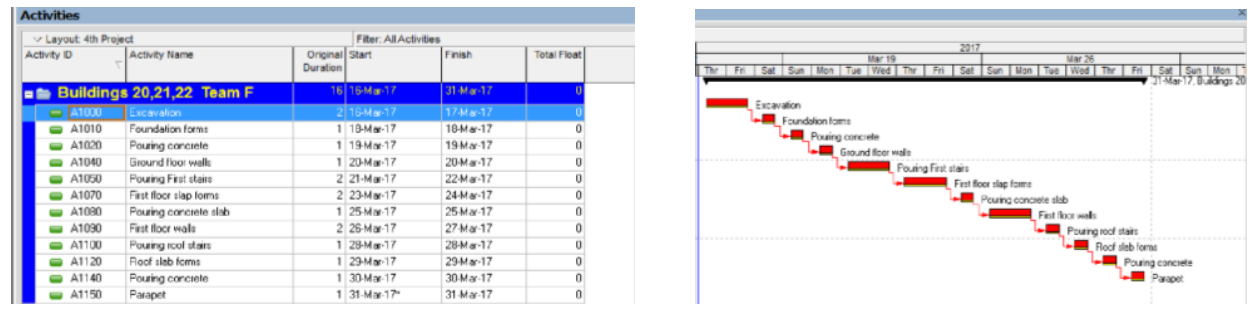

Fig. 7. Primavera P6 Scheduling

And then, the students were asked to import their 3D Revit model and Primavera P6 file into Navisworks which is a $4 \mathrm{D} / 5 \mathrm{D}$ simulation software tool for the purpose of creating 4D and 5D simulation model and had completed to connect all construction components, such as footing, beam, slab, wall, column, door, window etc, in their 3D Revit model with Navisworks Timeliner's activities that were originated from the BOQ items.

Consequently, they had finalized the $4 \mathrm{D} / 5 \mathrm{D}$ simulation Model that contain a lot of information, construction date $\&$ duration, project budget in accordance with the construction progress rate (Figure 8).
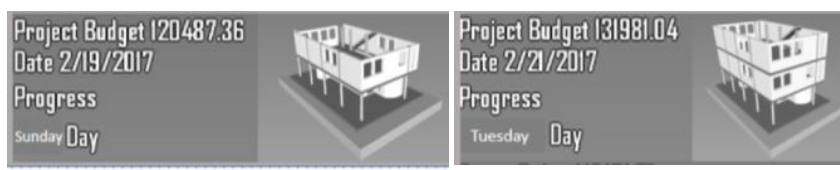


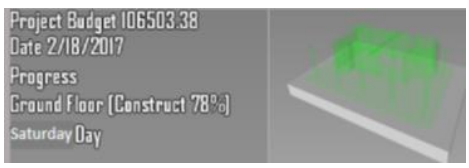

Fig. 8. 4D and 5D Simulation

\subsection{Model clash detection}

The clash detection process also had been performed for the purpose of finding out the modeling mistakes in terms of quality management. The function of Navisworks' clash detective was used in order to solve clash problems.

\section{BIM education guideline and expected outcome for KSA}

\subsection{BIM education guideline for KSA}

As mentioned in the case of PSU BIM education program, the BIM education guideline for KSA could be presented as follows:

- Theoretical knowledge to understand the meaning of BIM in the AEC industry

-3D building modeling skill by using BIM software tools

- Quantity takeoff and cost estimation from BIM model

-4D and 5D simulation modeling for time \& cost management

- Clash detection for model quality

Additionally, the building energy analysis should be included in the BIM education guideline even though it is not mentioned in this study.

\subsection{Expected outcome of the BIM education program in KSA}

The national BIM guideline is expected to be enacted by Saudi Arabia government in the near future, which means that the AEC industry of KSA begins to change from conventional $2 \mathrm{D}$ based process to $3 \mathrm{D}$ based BIM process. In the beginning stage to adopt BIM technology, the 3D based BIM design in the architecture area would be firstly performed in accordance with the requirements of KSA's AEC industrial market. And also, in the construction area, the clash detection process between architectural, structural and MEP's BIM models as the aspect of the quality management would be applied mainly for building projects. In this regard, the AEC industry in KSA can expect to nurture welltrained architects, engineers and other professionals through the proper BIM education program. Fisrt of all, well-trained BIM professionals in the initial stage to adopt BIM in KSA cannot be nurtured simply by teaching BIM software tools but can be caltivated through the right education program that is on the basis of the integrated understanding about BIM process as a new technology in the KSA's AEC industry.

\section{Conclusions}

The study presents a BIM education program as one of the regular engineering management course at Prince Sultan University on the basis of the last 3 years' course experience.

Firstly, the paper looked at the meaning of BIM as a new paradigm shift in AEC industry. A lot of national governments have mandated BIM as a national standard in order to enhance the productivity of their AEC industry. Secondly, the paper shows BIM education courses that are currently being carried out around the world. Many countries 
have specific BIM education program on the public and non-public sectors as well as wellorganized BIM education institutes for the future architects and civil engineers including current professionals. Thirdly, the paper considered the BIM course at PSU, "EM428, BIM Construction Management" as a proposed BIM education program. Fourthly, the paper introduced the students' outcomes of PSU BIM. During the course, the students had accomplished the following outcomes: (1) produce a BIM 3D model by using Revit and Tekla Structure in accordance with the various 2D drawings provided by the course instructor, (2) extract all related materials from the Revit model in order to estimate each materials' quantity, (3) document a BOQ in compliance with the material quantity extracted from the Revit model, (4) import the Revit model and Primavera P6 file into Navisworks for the purpose of creating 4D and 5D simulation model, (5) setup the clash detection process in terms of finding out the modeling mistakes. Lastly, the paper proposed BIM education guideline for KSA on the basis of the presented PSU BIM education program.

In fact, KSA's BIM education is still in its infancy so that it is now very important for the future Saudi architects and civil engineers to build up the proper BIM education program by Saudi AEC education providers, such as universities, colleges, engineering institutes, AEC companies. In this respect, the EM428, BIM Construction Management course at PSU could be one of good examples for the BIM education program. Hopefully, the more studies of BIM education program should be done in the near future.

\section{References}

1. Pikas, E., R. Sacks, and O. Hazzan., Building Information Modeling education for construction engineering and management, II: Procedures and implementation case study, Journal of Construction Engineering and Management, 139(11), (2013)

2. McGraw-Hill, The Buisiness Value of BIM in the South Korea: How Building Information Modeling Is Driving Positive Change in the South Korean Construction Industry, SmartMarket Report, McGraw-Hill Construction, (2012)

3. Brad Hardin and Dave Mccool., BIM and Construction Management, $2^{\text {nd }}$ Edition, Wiley \& Sons, Inc., Indianapolis, Indiana, (2015)

4. BAF, Embedding Building Information Modeling (BIM) within the taught curriculum, The Higher Education Academy Innovation Way, Heslington, York, (2013)

5. Nathan Blinn., and Raja R. A. Issa., Enhancing BIM Educational Experiences with Integrated Keystroke Capture Software, $10^{\text {th }}$ BIM Academic Symposium \& Job Task Analysis Review, Orlando, FL, April 4-5, pp.102, (2016)

6. Wang, L., and Leite, F., Process-Oriented Approach of Teaching Building Information Modeling in Construction Management, Journal of Professional Issues in Engineering Education and Practice, October 2014, vol. 140, issue 4, pp. 04014004-8, (2014)

7. Ali Abbas, Zia Ud Din, Rizwan Farooqui., Integration of BIM in construction management education: an overview of Pakistanni Engineering universities., International Conference on Sustainable Design, Engineering and Construction, Procedia Engineering 145, pp. 152., (2016) 